\title{
Disturbance and recovery following catastrophic grazing: studies of a successional chronosequence in a seagrass bed
}

\author{
Bradley J. Peterson, Craig D. Rose, Leanne M. Rutten and James W. Fourqurean
}

Peterson, B. J., Rose, C. D., Rutten, L. M. and Fourqurean, J. W. 2002. Disturbance
and recovery following catastrophic grazing: studies of a successional chronosequence in a seagrass bed. - Oikos 97: 361-370.

In August 1997, a large aggregation of the common sea urchin, Lytechinus variegatus, was discovered moving southward through a lush and productive seagrass monoculture of Syringodium filiforme in the Florida Keys, FL. Sea urchin densities at the grazing front were greater than 300 individuals $\mathrm{m}^{-2}$ which resulted in the overgrazing of seagrasses and a complete denuding of all vegetation from this area. The steady rate of the grazing front migration permitted the estimation of the time since disturbance for any point behind this grazing front allowing the use of a chronosequence approach to investigate the processes early on in succession of these communities.

In May 1999, six north-south parallel transects were established across the disturbed seagrass communities and into the undisturbed areas south of the grazing front. Based on the measured rates of the migration of the grazing front, we grouped 60 sites into five categories (disturbed, recently grazed, active grazing front, stressed and undisturbed). The large scale loss of seagrass biomass initiated community-wide cascading effects that significantly altered resource regimes and species diversity. The loss of the seagrass canopy and subsequent death and decay of the below-ground biomass resulted in a de-stabilization of the sediments. As the sediments were eroded into the water column, turbidity significantly increased, reducing light availability and significantly reducing the sediment nitrogen pool and depleting the seed bank. The portion of the chronosequence that has had the longest period of recovery now consists of a mixed community of seagrass and macroalgae, as remnant survivors and quick colonizers coexist and jointly take advantage of the open space.

B. J. Peterson, C. D. Rose, L. M. Rutten and J. W. Fourqurean, Dept of Biol. Sci. and Southeast Environm. Res. Center, Florida Int. Univ., University Park, Miami, FL 33199, USA (petersob@fiu.edu).

Communities exist in a continual state of flux. The concept of succession emphasizes this dynamic nature of communities. Disturbance has been identified as potentially the most important mechanism in structuring localized communities (Menge et al. 1999). Disturbance removes individuals from the community and thereby creates opportunities for new species to colonize, changing the community structure. Thus, disturbance rewinds the successional clock, driving the community further away from equilibrium or the climax community (Sousa 1984, Reice 1994). The trajectory of community development following a disturbance results from the dynamics between the length of time since the last disturbance, the strength of the disturbance, the historical species composition of the community, the probability of colonization of the area by individual species, and the resource supply rates (Grime 1979, Tilman 1988).

The study of succession is hampered because of the slow pace of change in most plant communities; hence, it is relatively rare for descriptions of community succession to come from observations of changes through time. Rather, ecologists often recognize a successional pattern through the observation of a chronosequence,

Accepted 6 February 2002

Copyright (C) OIKOS 2002

ISSN 0030-1299

OIKOS 97:3 (2002) 
or a mosaic of patches of habitat that have been developing for different periods following a disturbance. Such observations of chronosequences were important in formulating the model of succession in tropical New World seagrass beds (Den Hartog 1971, Patriquin 1975, Zieman 1982). Physical erosional features called blowouts "migrate" across seagrass beds in high-energy environments, removing stands of the dominant, slow-growing seagrass Thalassia testudinum and leaving a mosaic of patches of differing age since disturbance. In the youngest patches, only microalgae live in the unconsolidated sediment. Macroalgae dominate slightly older patches, while fast-growing seagrass species like Halodule wrightii and Syringodium filiforme are common in patches that are yet older. In patches that have existed for over 10 years since the last disturbance, $T$. testudinum is once again the dominant species.

Succession in tropical New World seagrass beds does not always result in a Thalassia testudinum-dominated climax community. This community is strongly affected by the availability of resources (Williams 1990, Fourqurean et al. 1995). Seagrass successional pathways may climax with Halodule wrightii if nutrient availability is high (Powell et al. 1989, Fourqurean et al. 1995), or a mixed species community may persist if the outcome of competition is influenced by a frequent disturbance regime or by environmental fluctuations which favor earlier successional species. For example, T. testudinum has a higher light requirement than other co-occurring seagrass species (Wiginton and McMillan 1979), so areas of low light availability are dominated by other seagrass species.

In August 1997, a large aggregation (extending the width of $>3.1 \mathrm{~km}$ ) of the common sea urchin, Lytechinus variegatus, was discovered moving in a general southward direction through a lush and productive seagrass meadow of Syringodium filiforme in the Florida Keys, FL, USA, at a rate of ca 1 linear meter day $^{-1}$ (Rose et al. 1999). Sea urchin densities at the grazing front were greater than 300 individuals $\mathrm{m}^{-2}$ and reported to be as high as ca 600 individuals $\mathrm{m}^{-2}$ (Maciá and Lirman 1999); these uncommonly high densities resulted in the overgrazing of seagrasses and an almost complete denuding of all vegetation from this area (Rose et al. 1999). The immediate impacts of this disturbance included loss of habitat, reduction of productivity, erosion of fine-grained sediments, the creation of a turbid sediment plume and reduced biodiversity of molluscan infaunal communities (Rose et al. 1999). This slow-moving disturbance provided an opportunity to study the time course of succession of this community because the steady migration rate of the grazing front allowed for the estimation of the time since disturbance for any point behind this advancing boundary. This allowed us to use the chronosequence approach to investigate the processes early on in succession of these communities (Pickett 1989).
In May 1999, we initiated a survey of a $4-5 \mathrm{~km}^{2}$ region of this overgrazed area with the following objectives: (1) to characterize the effect of the disturbance event on the physical parameters of the environment; (2) to determine the potential and extent of the recovery of the seagrass communities; and (3) to apply the chronosequence technique to address questions pertaining to the early successional pattern of this formerly Syringodium filiforme-dominated community.

\section{Methods}

\section{Study site}

Our study site was a $15 \times 3 \mathrm{~km}$ area located $20 \mathrm{~km} \mathrm{~N}$ of Marathon in the Florida Keys (ca $24^{\circ} 54^{\prime} \mathrm{N}, 81^{\circ} 06^{\prime}$ W) on the $\mathrm{N}$ edge of a $150 \mathrm{~km}^{2}$ meadow dominated by the seagrass Syringodium filiforme (Fig. 1). Water depth at the study area was $1.5-2 \mathrm{~m}$. A relatively thin veneer (ca $25 \mathrm{~cm}$ ) of calcareous, fine-grained sediment overlaid a microkarstic carbonate bedrock. In May 1999, six north-south parallel transects were established across the disturbed seagrass communities and into the undisturbed areas south of the grazing front. Ten sites were sampled along each transect. The first nine sites were separated by ca $0.25 \mathrm{~km}$, while the tenth site of each transect was ca $9-10 \mathrm{~km}$ south of the grazing front within the undisturbed S. filiforme meadow (Fig. 1). Between September 1996 and May 1999, the progression of the urchin grazing front was mapped five times. This allowed the study area to be divided into five discrete regions based on time since disturbance at the time of the survey.

\section{Field surveys}

All 60 sites were visited once on either May 17 and 18, 1999. At each site, secchi depth was recorded and unfiltered water samples for determination of turbidity were collected in duplicate $20 \mathrm{ml}$ plastic scintillation vials. Vials were filled approximately $10 \mathrm{~cm}$ below the surface. Turbidity was measured using a portable turbidimeter (HF Scientific, DRT-15CE) in Nephelometric Turbidity Units (ntu). Phytoplankton abundance was estimated from chlorophyll- $a$ (Chl- $a$ ) concentrations which were determined by collecting $240 \mathrm{ml}$ of water at each site approximately $10 \mathrm{~cm}$ below the surface and filtering it through $25 \mathrm{~mm} \mathrm{GF} / \mathrm{F}$ glass fibre filters. The filters were placed in $2.0 \mathrm{ml}$ spectrophotometric grade acetone in capped vials and stored on ice in the dark for transportation to the laboratory. Acetone extractions were continued for $48 \mathrm{hr}$ before Chl- $a$ content was determined fluorometrically (Strickland and Parsons 1972). 
Divers used SCUBA to conduct surveys of the benthos at each site using a modified Braun-Blanquet (BB) scoring technique (Fourqurean et al. 2001). Five haphazard quadrats $\left(0.25 \mathrm{~m}^{2}\right)$ were used to sample sea urchin densities, seedling densities of Syringodium filiforme, and frequency, density and abundance of benthic plant taxa. Sediment depth was also recorded to the nearest $\mathrm{cm}$.

Replicate $2 \mathrm{ml}$ sediment samples of the top $5 \mathrm{~cm}$ were collected from each site using separate small cores $(5 \mathrm{ml}$ syringes with the tips removed) and were analyzed for elemental content (total $\mathrm{C}, \mathrm{N}$ and $\mathrm{P}$ ), porosity, total organic matter, and sediment Chl- $a$ concentrations. Replicate sub-samples (ca $5 \mathrm{mg}$ ) were used to determine organic $\mathrm{C}$ and total $\mathrm{N}$ content using a $\mathrm{CHN}$ analyzer (Fisons NA1500), and replicate $20 \mathrm{mg}$ sub-samples were used to determine $\mathrm{P}$ content using a dry oxidation/ acid-hydrolysis procedure (Solorzano and Sharp 1980). All elemental ratios are presented on a $\mathrm{mol} / \mathrm{mol}$ basis.

Sediments from replicate $5 \mathrm{ml}$ cores were placed in pre-weighed, glass $20 \mathrm{ml}$ scintillation vials and stored on ice. Benthic microalgae abundance was estimated by sediment Chl- $a$, extracted by adding acetone $(15 \mathrm{ml})$ to sediment samples from one core. The supernatant was decanted out of the vials and Chl- $a$ levels were determined fluorometrically as described above. The second sediment sample was dried to a constant mass at $60^{\circ} \mathrm{C}$ and weighed to obtain a percent water content. Dried samples were then ashed for four hours at $500^{\circ} \mathrm{C}$ to determine total organic matter.

Ten short shoots of Thalassia testudinum were collected at each site (when present) for leaf elemental analyses and epibiont biomass. Syringodium filiforme, the dominant seagrass species prior to the overgrazing event, was not used for this because it was entirely removed from the majority of sites behind the grazing front. In the laboratory, the leaf number, width, length and epibiont mass $\left(\mathrm{mg} \times \mathrm{g}\right.$ leaf dry $\left.\mathrm{wt}^{-1}\right)$ were determined. Epibiont mass was ascertained by gently scraping fouling organisms and algae from each leaf then drying them to a constant mass $( \pm 0.01 \mathrm{mg})$ in an oven at $60^{\circ} \mathrm{C}$. To assess any nutrient availability changes to macrophytes that survived the overgrazing, we measured tissue $\mathrm{C}, \mathrm{N}$ and $\mathrm{P}$ content in Thalassia testudinum leaves (Atkinson and Smith 1983, Fourqurean et al. 1992).

One large core $(\mathrm{id}=16 \mathrm{~cm})$ was used to collect seagrass above- and below-ground biomass and sediment at each site. Each core extended to the limestone bedrock and contained the entire sediment profile. In the laboratory, both seagrasses, Syringodium filiforme and Thalassia testudinum, were separated from the mud, rinsed, divided into their component organs (leaves, short shoots, rhizomes and roots), dried to
Fig. 1. Site map of the chronosequence area. A) Site locations and time lines of the grazing front displayed.

B) Site location and Syringodium filiforme distribution within south Florida

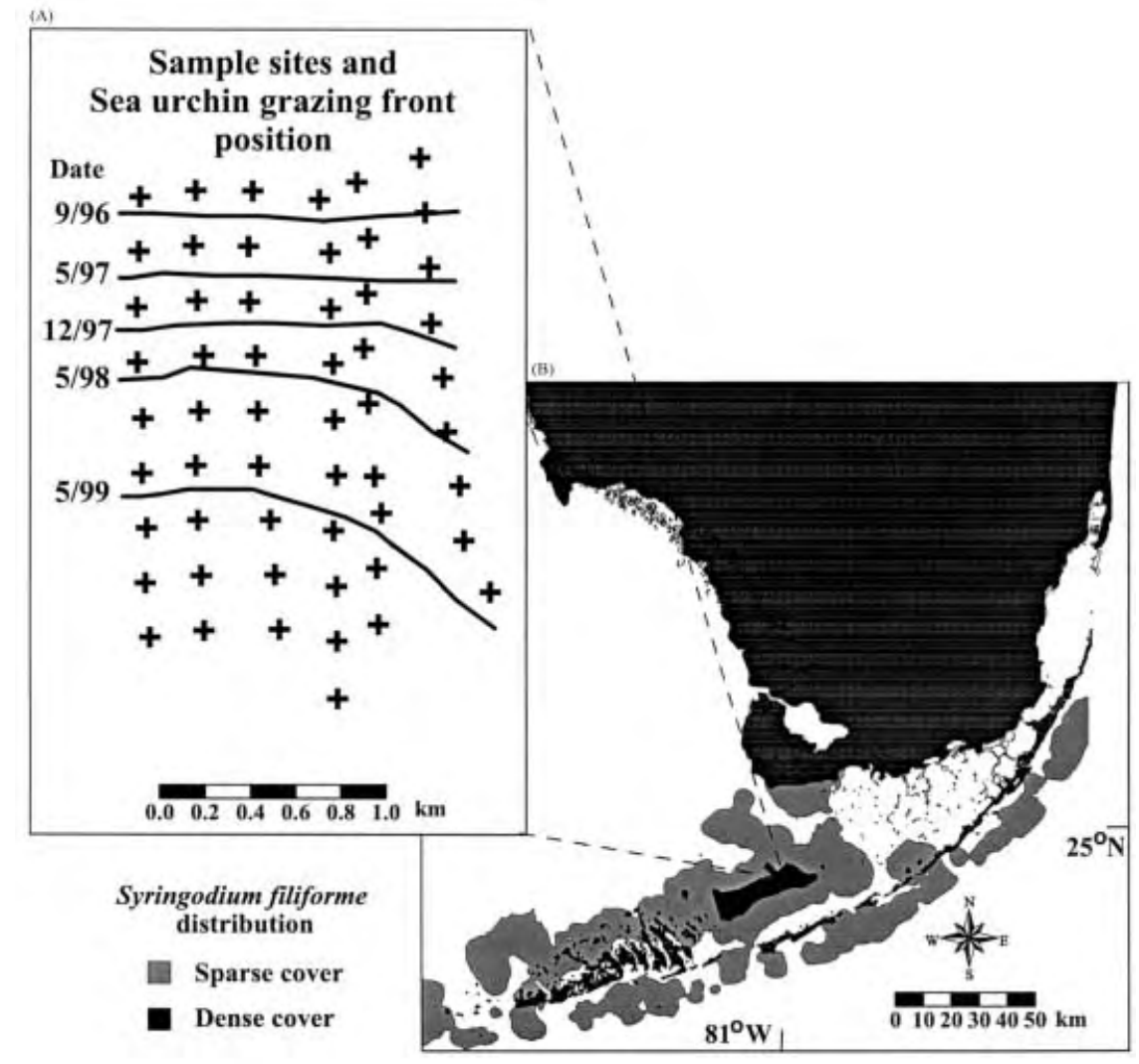


constant mass, and weighed. The numbers of short shoots and apical meristems were also recorded. Total biomass, short shoot density, standing crop, and biomass allocation were determined. Sediments collected in the cores were sieved in order to enumerate Syringodium filiforme seeds. All data are presented on a $\mathrm{m}^{-2}$ basis.

\section{Statistical analysis}

Based on the measured rates of the migration of the grazing front, we grouped the 60 sites into five categories (from north to south): disturbed (DI), the region of the chronosequence that the urchin front had passed through over 2 yrs prior; recently grazed $(\mathrm{RG})$, the area that had been disturbed $<2$ yr ago but $>1$ yr; active grazing front $(\mathrm{GF})$, the portion of the chronosequence that had been disturbed $<1 \mathrm{yr}$; stressed (ST), the area immediately in front of the active grazing front that had not been grazed but was experiencing reduced light levels as the turbid sediment plume expanded toward the south over these sites; and undisturbed (UN), the region south of the turbid waters, completely removed from the urchin overgrazing event $(9-10 \mathrm{~km})$, and not affected at the time of our sampling, either directly or indirectly, by the overgrazing event (Fig. 1). Comparisons of the physical and biotic parameters between categories were made using one-way ANOVA. When a significant effect on the response variable was found, multiple comparison tests (Tukey's Studentized Range) were used to test for significant differences between regions within the study area. In addition, Pearson two-tailed significance tests were conducted to test for correlations between Thalassia testudinum leaf tissue nutrient content and sediment nutrient content.

\section{Results}

\section{Physical parameters}

Knowing the linear movement of the sea urchin grazing front allowed us to examine the rate of change of the environment by substituting distance for time using the chronosequence approach. The disturbance of the urchin grazing event had significant effects on the seagrass community. Following urchin grazing, there was an erosion of sediments and a concomitant decrease in water clarity in the seagrass meadows (Fig. 2). Sediment depth $(p<0.01)$ and porosity $(p<0.01)$ also decreased following the disturbance. In addition, the sediment nutrient regime was altered. The sediment nitrogen pool was significantly reduced. This pattern was reflected in the sediment organic $\mathrm{C}: \mathrm{N}$ ratio which increased from 45 to 165 , and N:P ratios which decreased from 24 to 4 with distance from the pre-front
Syringodium filiforme beds. However, the organic C:P ratio of the sediments was unaffected by the disturbance $(p=0.16)$.

Although we did not directly measure nutrient efflux from the sediment as a result of grazing, two environmental parameters that responded to this efflux were assessed (benthic microalgal abundance and epiphyte biomass). Both benthic microalgae and epiphyte biomass significantly increased with time since grazing ( $p<0.001$ and $p<0.01$, respectively), indicating an increase in nutrient availability to these groups of organisms.

Thus, the region of the chronosequence that had experienced the greatest length of time since the disturbance event (DI) possessed sediments that had the shallowest depths, the lowest porosities, the lowest nitrogen levels and the highest benthic microalgae abundance. This region also contained the most turbid overlying water column with the highest phytoplankton abundance. In contrast, the area farthest removed from the active grazing front (UN) had sediments with the deepest depths, the highest porosities and the highest nitrogen levels. This region also possessed the least turbid overlying water column with the lowest phytoplankton abundance and sediments with the lowest benthic microalgae abundance.

\section{Community composition}

High densities of Syringodium filiforme (BB densities $=$ $4-5$; which is ca $75-100 \%$ cover) were observed immediately before the grazing front (south), while post-front sites (to the north) were almost completely denuded, except for small isolated surviving islands of low density $S$. filiforme (Fig. 3A). The density of $S$. filiforme was significantly different between the five regions of the chronosequence ( $p<0.001$; Fig. 4A). Regrowth of $S$. filiforme was observed at some of the DI sites that had been disturbed the earliest. However, densities remained very low. Syringodium filiforme seedling densities were as high as 20 seedlings $\mathrm{m}^{-2}$ (Fig. 3B) and were most abundant in the RG area immediately behind (north) the active grazing areas (i.e. areas where sea urchins were still present). Seedling densities were also significantly different between the five regions of the chronosequence ( $p=0.003$; Fig. 4B). Seedling densities decreased with distance from the grazing front. No seedlings were observed under the seagrass canopy in the UN sites. Syringodium filiforme seed densities ranged from $0-280$ seeds $\mathrm{m}^{-2}$ (Fig. 3C) and were predominantly found in the ungrazed $S$. filiforme communities. Seed densities were significantly different between the different regions of the chronosequence ( $p=0.038$; Fig. $4 \mathrm{C})$ and decreased along the time since disturbance axis. Sediment depth and seed densities were significantly correlated $(p=0.02)$. As sed- 

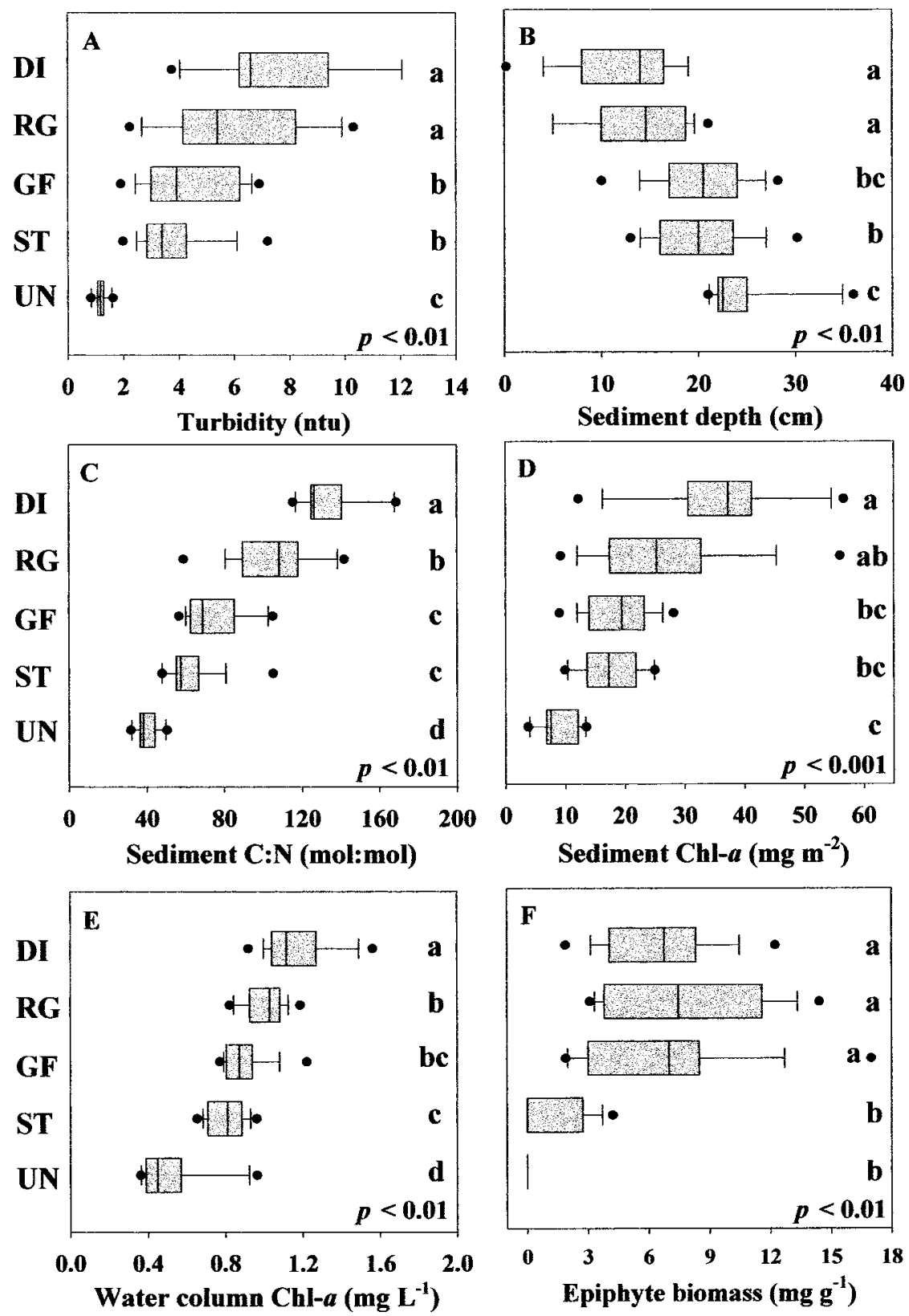

Fig. 2. Physical and biotic parameters of the chronosequence. A) Turbidity. B) Sediment depth. C) Sediment C:N ratio. D) Sediment Chl- $a$. E) Water column Chl- $a$. F) Epiphyte biomass. (Note: UN = undisturbed area approximately $5 \mathrm{~km}$ removed from the grazing event; ST = stressed Syringodium filiforme area which was adjacent to the final site of the sea urchin front but was not grazed; $\mathrm{GF}=$ the area of the chronosequence that was affected last by the grazing front; $\mathrm{RG}=$ the recently grazed area of the chronosequence where the Syringodium filiforme was removed by sea urchin grazing; and DI = the area of the chronosequence that has experienced the greatest length of time since the disturbance. Lines within the box plots show median values. The black circles represent the 5 th and 95 th percentile. Error bars $=$ SD. Letters indicate significant differences between regions by Tukey's multiple comparisons test; $p=0.05$.)

iment depth decreased along the chronosequence, seed density decreased as well.

The plant community composition across the chronosequence changed dramatically (Fig. 3 and 5). Thalassia testudinum density was significantly different between the five regions of the chronosequence ( $p=$ 0.009; Fig. 5). The patterns of increasing density for $T$. testudinum with time since disturbance were opposite to those observed for Syringodium filiforme. This trend was also observed for the biomass (above- and below- 
ground) of each seagrass species (Fig. 6). Similarly, densities for the calcareous algae Halimeda spp., Udotea spp., and Penicillus spp. were significantly different between the five regions of the chronosequence ( $p=0.04, p<0.001$ and $p=0.04$, respectively) and increased with increasing time since disturbance. Therefore, the pre-front area (both ST and UN sites) was primarily a dense $S$. filiforme seagrass monoculture with low densities of $T$. testudinum and calcareous green algas. The RG area (i.e. those sites immediately behind the active grazing front) was characterized by the lowest genus and taxon richness and by the highest densities of $S$. filiforme seedlings (Fig. 3 and 4). In contrast, the plant community composition of the DI that had the experienced the greatest length of time since disturbance was characterized by the early colonizing seagrass, Halodule wrightii, the fast growing calcareous algae, Caulerpa spp., Halimeda spp., Penicillus spp., and Udotea spp., and the remnant patches of T. testudinum which is the most resistant to overgrazing of the three seagrasses in the study site.

\section{Discussion}

Catastrophic mortality as a result of large scale disturbances has been invoked as a mechanism which promotes species diversity and prevents a system from achieving equilibrium or becoming a climatic successional stage (Huston 1994). Species diversity may be enhanced as the abundance of a dominant competitor is reduced or resource regimes are altered due to the loss of the dominant species or by physical changes to the environment. In our study, the large-scale loss of seagrass biomass initiated community-wide cascading effects that altered resource regimes and species diversity. The loss of the seagrass canopy and subsequent death and decay of the below-ground biomass resulted in a de-stabilization of the sediments. As the sediments eroded into the water column, turbidity increased reducing light availability, reducing the sediment nitrogen pool and depleting the seed bank.

\section{Changes in the resource regimes}

Seagrass communities are primarily limited by either nutrients (nitrogen or phosphorus) or light availability (Dennison 1987, Hemminga et al. 1991). A commonly accepted paradigm suggests that seagrasses in the tropics tend to be P-limited as carbonate sediments adsorb free phosphate from the water column; seagrasses in environments with terrigenous sources of sediment tend to be N-limited, and seagrasses in eutrophic or nutrientrich environments tend to be light limited (Short 1987).

In outer Florida Bay, Syringodium filiforme dominates the landscape. Clear waters in a shallow environment $(<4 \mathrm{~m})$ and relatively greater $\mathrm{P}$ availability allow for high productivity and luxuriant growth of $S$. filiforme which has the capacity to exclude the presence of other seagrasses and macroalgae (Kenworthy and Schwarzschild 1998). Sea urchin overgrazing has altered the resource availability in this area. The initial loss of the seagrass canopy has had several direct and indirect effects on the local resource regimes. Syringodium filiforme leaves contain large lacunae (air spaces) and are thus buoyant. When cut from their short shoots, they float to the surface and form large wracks of detritus that drift away from the system resulting in a direct loss of sequestered nutrients. Rose et al. (1999) predicted that after one year of sea urchin overgrazing in outer Florida Bay $578981 \mathrm{~kg}$ dwt of S. filiforme would be lost from the system. This suggests that a large amount of organic material and nutrients in the form of plant biomass was removed from the disturbed areas.

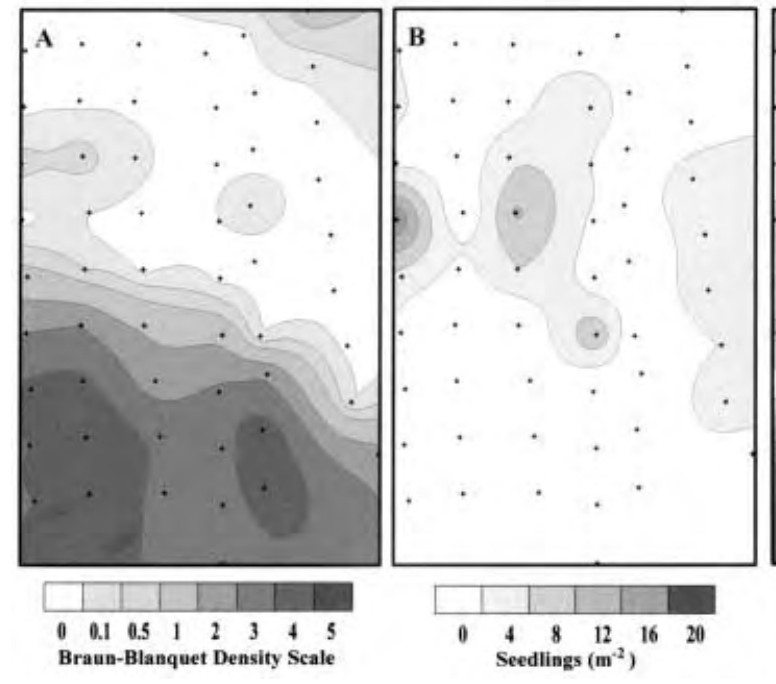

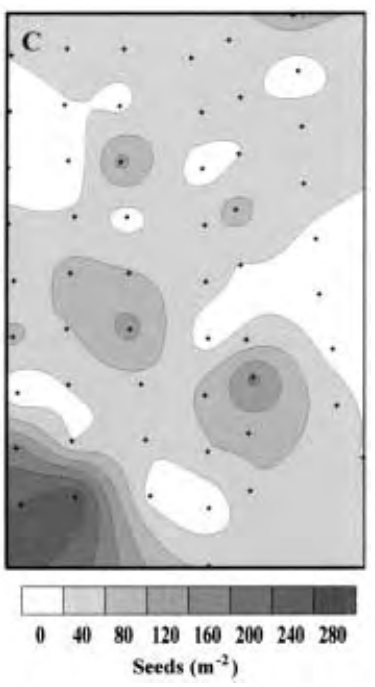

Fig. 3. Spatial contours of Syringodium filiforme parameters across the chronosequence. A) Braun-Blanquet density of above-ground biomass. B) Density of $S$. filiforme seedlings. C) Density of $S$. filiforme seeds. 

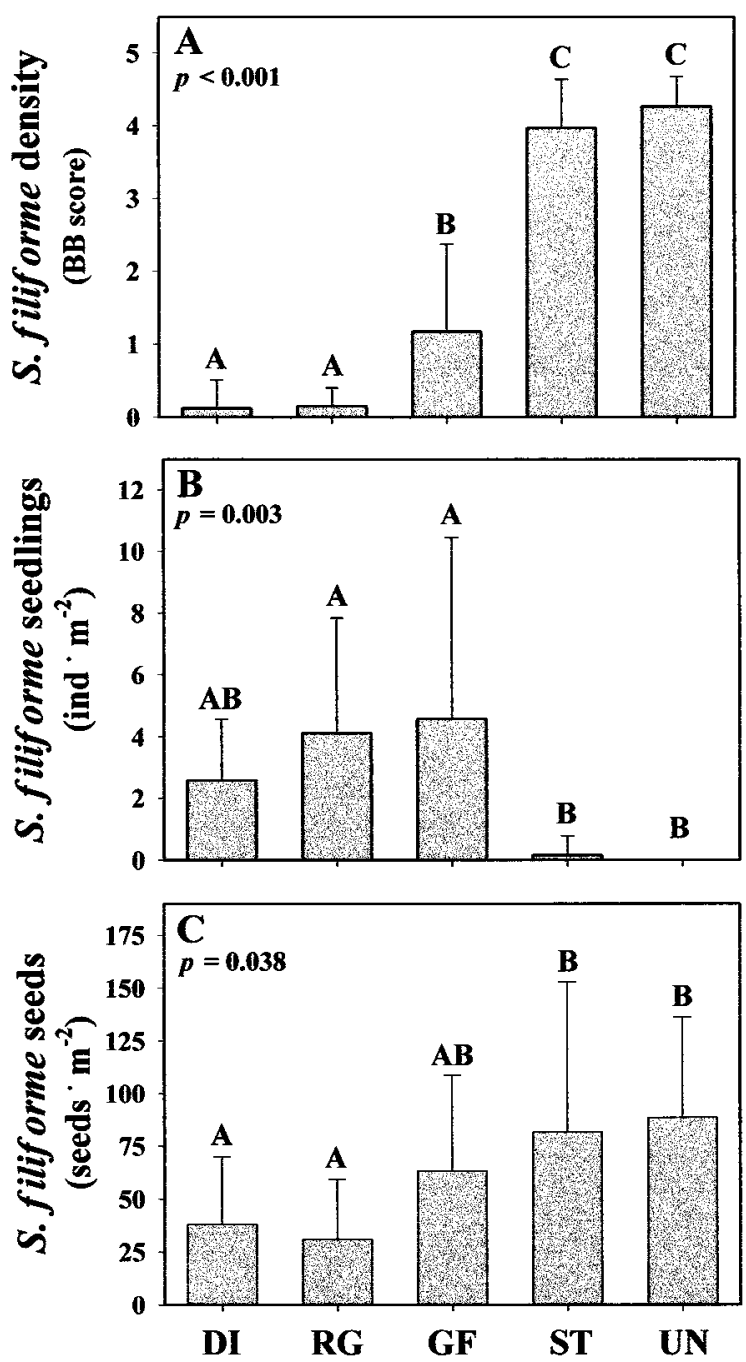

Fig. 4. Plots of Syringodium filiforme parameters across the chronosequence. A) Braun-Blanquet density of above-ground biomass. B) Density of $S$. filiforme seedlings. C) Density of $S$ filiforme seeds. (Note: Error bars $=\mathrm{SD}$. Letters indicate significant differences between regions by Tukey's multiple comparisons test; $p=0.05$.)

In addition to this export of sequestered nutrients in the plant biomass, the loss of the $1 \mathrm{~m}$ tall seagrass canopy and the death and decay of the root-rhizome matrix have caused significant sediment erosion within the overgrazed areas, subsequently reducing the sediment nitrogen pool. The winnowing of fine-grained particles has reduced sediment organic matter and $\mathrm{N}$ in the recently grazed (RG) and disturbed (DI) portions of the chronosequence. Higher phytoplankton biomass in the water column with time since disturbance suggests that the phytoplankton abundance increased in response to the release of sediment nutrients to the water column. It was not anticipated that phytoplankton biomass would remain high over time. However, the response of increased phytoplankton biomass as a con- sequence of the loss of the seagrass canopy has been previously observed in Florida Bay (Robblee et al. 1991, Fourqurean and Robblee 1999) where seagrass die-offs occurred, causing turbid plumes characterized by increased water column nutrients with plankton and algal blooms (Phlips and Badylak 1996, Stumpf et al. 1999). However, phytoplankton concentrations in the DI and RG were an order of magnitude higher than those reported by Boyer et al. (1999) for western Florida Bay, suggesting in the wake of urchin overgrazing that the nutrient load and sediment resuspension may be even greater than in the previously observed seagrass die-offs in Florida Bay. If the urchins were still present at the formerly high densities observed previously, one might suggest that the continual high phytoplankton biomass was a response to the continuing release of nutrients from their grazing activities. However, at the time of the survey, the urchin population was only a fraction of its previous density, and very few remained at the grazing front $\left(2-3\right.$ individuals $\left.\mathrm{m}^{-2}\right)$. In the overgrazed areas, in addition to the increased phytoplankton biomass, greater epiphytic biomass on surviving seagrasses provides further evidence for continued significant increases of water column nutrients, relative to the ST and UN areas of the chronosequence.

Higher epiphyte loads, increased plankton biomass, and sediment resuspension are not only signs of localized changes in the nutrient regimes, but also exhibit a direct impact on light availability. The loss of the seagrass canopy has created a turbid plume within this area which is continually propagated by the convergence of water masses from the eastern Gulf of Mexico, Florida Bay and the tidal fluctuations through the Florida Keys. Reduced light availability in the overgrazed areas was initially observed by Rose et al. (1999); measurements taken during this study and repeated visits to the overgrazed areas indicate that the recovery dynamics of this community may be affected as light availability remains lower than in nearby undisturbed seagrass beds. However, it is important to note that while the turbidity plume has reduced light levels reaching the canopy, the loss of the seagrass canopy has actually increased light levels reaching the sediment surface. Thus, the presence of increased benthic microalgae is likely due to increased light levels reaching the sediment surface resulting from the loss of the previous light barrier, the seagrass itself.

\section{Recovery dynamics and species diversity}

Disturbance effects on resource regimes and the ensuing successional dynamics of community recovery are well documented (Vitousek and Reiners 1975, Petraitis et al. 1989, Huston 1994). Major constraints on plants colonizing disturbed areas include access to the disturbed region, availability of limiting resources, and continual 
mortality. We observed similar constraints on the recovery of the older areas of the chronosequence in outer Florida Bay. Syringodium filiforme dominated this landscape prior to the sea urchin overgrazing, but successional vectors may now be altered due to reduced sediment nutrients, light availability and suitable substrate, in addition to continual mortality from erosion and light stress. If these limitations have a greater adverse effect on the recolonization potential of $S$. filiforme relative to other seagrass and macroalgal species, the previous state of dominance by $S$. filiforme will be replaced by a diverse assemblage of benthic vegetation which would be dependent on the dispersal ability and distribution of propagules from each species (Tilman 1994).

Successional studies in seagrass communities have shown that recolonization is directed by seed banks, vegetative propagules, and ramet expansion. The ramets would originate from isolated island patches within the bare area, or from the edges surrounding the disturbance. Birch and Birch (1984) observed that differences in the appearance and abundance of seagrass species after Cyclone Althea (December 24, 1971) denuded Cockle Bay (Queensland, Australia) were mainly due to differences in the rates of seed germination and flowering frequency. Rhizome expansion was cited to be of secondary importance at the scale of the community; however, regeneration by rhizome expansion was of primary importance for late stage dominants and rare sub-dominants within the community. The overall importance and role of seed recruitment in the recolonization of disturbed communities is not as well known for seagrasses in the Caribbean and Gulf of Mexico. In our study, seed densities had a range of $0-280 \mathrm{~m}^{-2}$, and seedling densities ranged between $0-20 \mathrm{~m}^{-2}$ (with one site having densities as high as $80 \mathrm{~m}^{-2}$ ). The highest number of seeds corresponded to dense, undisturbed portions of the chronosequence, and the seedlings were mostly found immediately behind the grazing front. These data suggest that a seed bank is present and that seedlings can grow in this environment, but may be limited (possibly by light availability under the canopy) in the dense, undisturbed seagrass beds. Once the canopy was removed, the seeds germinated, but they did not persist over time. Both seed and seedling densities decreased with distance from the grazing front. The lack of seeds and seedlings in the oldest portions of the chronosequence is presumably due to erosion and sediment resuspension which would remove the seeds and uproot the germinating seedlings. No seeds and seedlings from other species were observed. Our data suggest that Syringodium filiforme seed recruitment and seedling success is minimal in the disturbed areas of the chronosequence due to inadequate sediment depth and stability, thus limiting its contribution toward the potential recovery of the overgrazed area.

Braun-Blanquet surveys revealed that surviving patches of Syringodium filiforme were present throughout the chronosequence, along with expanding patches of the seagrasses Thalassia testudinum and Halodule wrightii and two macroalgal groups, Caulerpa spp. and calcareous green algae (i.e. Halimeda spp., Penicillus spp., and Udotea spp.). The lack of seeds and seedlings for either $S$. filiforme or $T$. testudinum indicates that ramet expansion from surviving patches is the primary mechanism of recovery for these seagrasses. Both $S$. filiforme and $T$. testudinum produce seeds that are negatively buoyant, thus limiting the possibility of seed recruitment into the disturbed area. It appears that as the urchin grazing front passed through the seagrass bed, the few patches of $T$. testudinum present within the

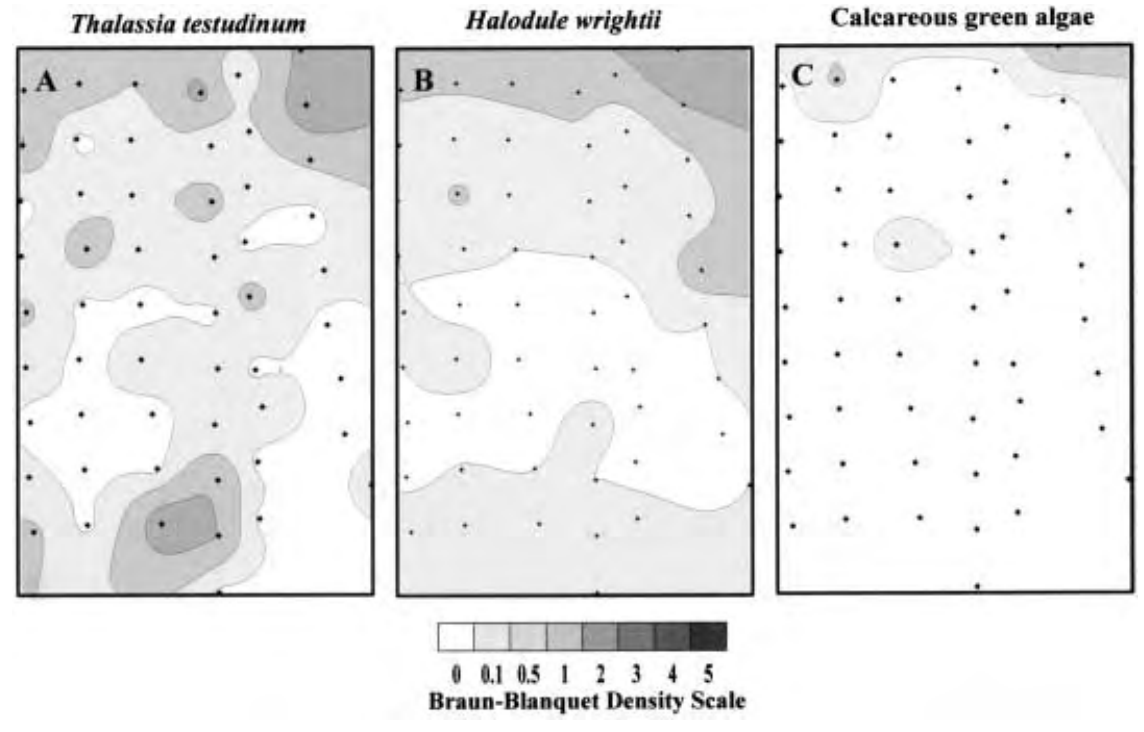

Fig. 5. Spatial contours of Braun-Blanquet density values. A) Thalassia testudinum. B) Halodule wrightii. C) Total calcareous green algae. 
Fig. 6. Plots of the seagrass biomass distribution across the chronosequence. A) Syringodium filiforme above-ground biomass. B) $S$. filiforme below-ground biomass. C) Thalassia testudinum above-ground biomass. D) T. testudinum below-ground biomass. (Note: Error bars $=\mathrm{SD}$. Letters indicate significant differences between regions by Tukey's multiple comparisons test; $p=0.05$.)
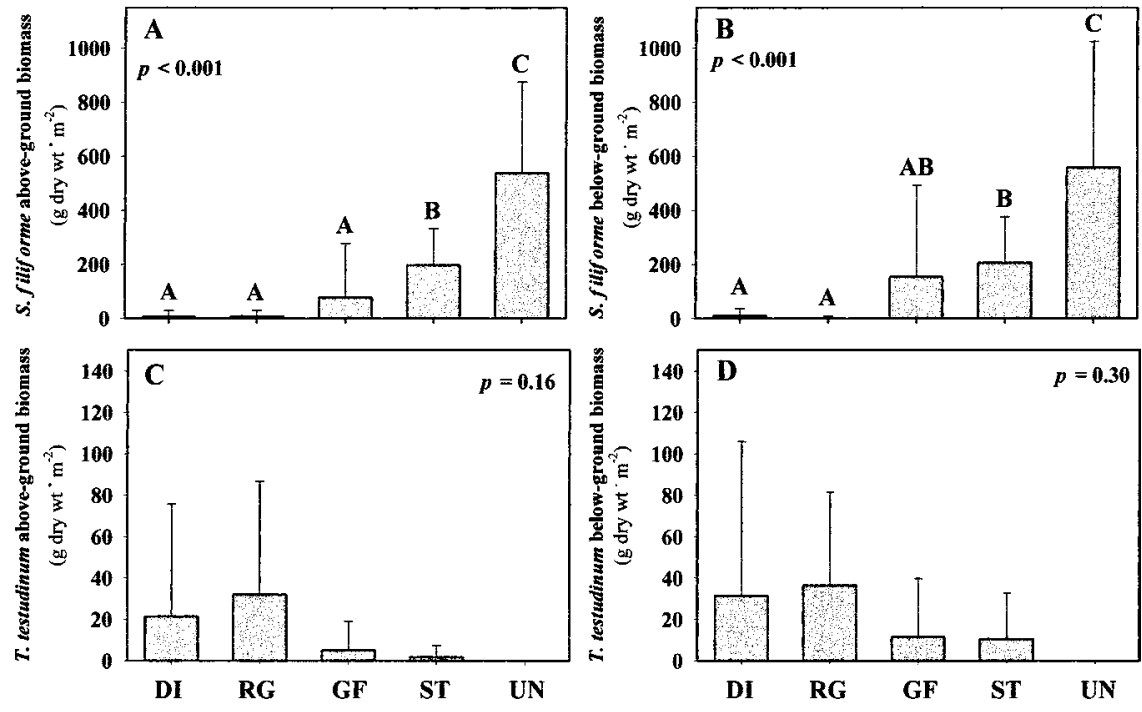

S. filiforme canopy immediately re-established their above-ground biomass and began to expand into the newly opened space. This is possible because $T$. testudinum possesses a large below-ground reserve. $S y$ ringodium filiforme lacks this reserve and thus is more vulnerable to overgrazing. Halodule wrightii, which is considered a colonizing seagrass species, has begun to establish itself in the oldest portion of the chronosequence.

Traditional models of seagrass succession in Caribbean communities suggest that bare areas are colonized along a trajectory that begins with rhizophytic algae and progresses through stages of dominance by Halodule wrightii and Syringodium filiforme until it ends with a relatively undisturbed, monotypic community dominated by Thalassia testudinum (Den Hartog 1971, Zieman 1982). The initial stages of this pattern is reflected along the chronosequence. However, the final outcome of succession in this area remains unknown. The previous dominance by $S$. filiforme in outer Florida Bay has been related to higher nutrient availability (Fourqurean et al. 2002), but recovery may now be limited by reduced resource availability, which may favor species which have lower resource requirements and/or increased growth potential or survival in these open environments.

Seagrass beds are valued for the services they provide to the overall function of coastal marine ecosystems (Hemminga and Duarte 2000). They increase coastal biodiversity by providing habitat for many organisms and by functioning as nursery and foraging areas for many animals. In addition, they improve water quality by reducing suspended sediments and by absorbing nutrients, and they stabilize sediments. Our results indicate that the loss of the seagrass canopy because of a disturbance leads to the loss of these services and therefore deteriorate of water quality, increase erosion and lose habitat value. The oldest portion of the chronosequence had the lowest light availability but the highest diversity with eight seagrass and macroalgal species. Low resource availability may inhibit $S y$ ringodium filiforme in achieving its previous state of dominance in this area. It appears that at least for the immediate future the overgrazed area will consist of a mixed community of seagrass and macroalgae, as remnant survivors and quick colonizers coexist and jointly take advantage of the open space.

Acknowledgements - The authors would like to thank Sean Meehan and Kevin Cunniff for field assistance. This study was supported by the Tropical Biology Program at Florida International University from a grant awarded to C.D.R. and by the USEPA Water Quality Protection Program from the Florida Keys National Marine Sanctuary (Grant \# X994620-945). This project is contribution \# 48 of the Tropical Biology Program at Florida International University and contribution \# 173 of the Southeast Environmental Research Center.

\section{References}

Atkinson, M. J. and Smith, S. V. 1983. C:N:P ratios of benthic marine plants. - Limnol. Oceanogr. 28: 568-574.

Birch, W. R. and Birch, M. 1984. Succession and pattern of tropical intertidal seagrasses in Cockle Bay, Queensland, Australia: a decade of observations. - Aquat. Bot. 19: $343-367$.

Boyer, J. N., Fourqurean, J. W. and Jones, R. D. 1999. Seasonal and long-term trends in the water quality of Florida Bay (1989-1997). - Estuaries 22: 417-430.

Den Hartog, C. 1971. The dynamic aspect in the ecology of seagrass communities. - Thalassia Jugosl. 7: 101-112.

Dennison, W. C. 1987. Effects of light on seagrass photosynthesis, growth, and depth distribution. - Aquat. Bot. 27: $15-26$.

Fourqurean, J. W. and Robblee, M. B. 1999. Florida Bay: a history of recent ecological changes. - Estuaries 22: 345 357. 
Fourqurean, J. W. Zieman, J. C. and Powell, G. V. N. 1992 Phosphorus limitation of primary production in Florida Bay: evidence from the C:N:P ratios of the dominant seagrass Thalassia testudinum. - Limnol. Oceanogr. 37 $162-171$.

Fourqurean, J. W., Powell, G. V. N., Kenworthy, W. J. and Zieman, J. C. 1995. The effects of long-term manipulation of nutrient supply on competition between the seagrasses Thalassia testudinum and Halodule wrightii in Florida Bay. - Oikos 72: 349-358.

Fourqurean, J. W., Willsie, A. W., Rose, C. D. and Rutten, L. M. 2001. Spatial and temporal pattern in seagrass community composition and productivity in south Florida. Mar. Biol. 138: 341-354.

Fourqurean, J. W., Durako, M. J., Hall, M. O. and Hefty, L. N. 2002. Seagrass distribution in south Florida: a multiagency coordinated monitoring program. - In: Porter, J W. and Porter, K. G. (eds), The Everglades, Florida Bay, and the coral reefs of the Florida Keys. CRC Press.

Grime, J. B. 1979. Plant Strategies and Vegetation Processes. - John Wiley and Sons Ltd.

Hemminga, M. A. and Duarte, C. M. 2000. Seagrass ecology. - Cambridge Univ. Press.

Hemminga, M. A., Harrison, P. G. and van Lent, F. 1991 The balance of nutrient losses and gains in seagrass meadows. - Mar. Ecol. Prog. Ser. 71: 85-96.

Huston, M. A. 1994. Biological Diversity: the coexistence of species on changing landscapes. - Cambridge Univ. Press.

Kenworthy, W. J. and Schwarzschild, A. C. 1998. Vertical growth and short-shoot demography of Syringodium filiforme in outer Florida Bay, U.S.A. - Mar. Ecol. Prog. Ser. 173: $25-37$.

Maciá, S. and Lirman, D. 1999. Destruction of Florida Bay seagrasses by a grazing front of sea urchins. - Bull. Mar. Sci. 65: 593-601.

Menge, B. A., Daley, B. A., Lubchenco, J. et al. 1999 Top-down and bottom-up regulation of New Zealand rocky intertidal communities. - Ecol. Monogr. 69: 297330.

Patriquin, D. G. 1975. "Migration" of blowouts in seagrass beds at Barbados and Carriacou, West Indies, and its ecological and geological implications. - Aquat. Bot. 1: $163-189$.

Petraitis, P. S., Latham, R. E. and Niesenbaum, R. A. 1989 The maintenance of species diversity by disturbance. - Q . Rev. Biol. 64: 393-418.

Phlips, E. J. and Badylak, S. 1996. Spatial variability in phytoplankton standing stock and composition in a shallow innershelf lagoon, Florida Bay, Florida. - Bull. Mar. Sci. 58: 203-216.
Pickett, S. T. A. 1989. Space-for-time substitution as an alternative to long-term studies. - In: Likens, G. E. (ed.), Long-term studies in ecology: approaches and alternatives. Springer-Verlag, pp. 110-135.

Powell, G. V. N., Kenworthy, W. J. and Fourqurean, J. W. 1989. Experimental evidence for nutrient limitation of seagrass growth in a tropical estuary with restricted circulation. - Bull. Mar. Sci. 44: 324-340.

Reice, S. R. 1994. Nonequilibrium determinants of biological community structure. - Am. Sci. 82: 424-435.

Robblee, M. B., Barber, T. R., Carlson, P. R. et al. 1991. Mass mortality of the tropical seagrass Thalassia testudinum in Florida Bay (USA). - Mar. Ecol. Prog. Ser. 71: 297-299.

Rose, C. D., Sharp, W. C., Kenworthy, W. J. et al. 1999. Overgrazing of a large seagrass bed by the sea urchin Lytechinus variegatus in Outer Florida Bay. - Mar. Ecol. Prog. Ser. 190: 211-222.

Short, F. T. 1987. Effects of sediment nutrients on seagrasses: literature review and mesocosm experiment. - Aquat. Bot. 27: $41-57$.

Solorzano, L. and Sharp, J. H. 1980. Determination of total dissolved phosphorus and particulate phosphorus in natural waters. - Limnol. Oceanogr. 25: 754-760.

Sousa, W. P. 1984. The role of disturbance in natural communities. - Ann. Rev. Ecol. Syst. 15: 353-391.

Strickland, J. D. H. and Parsons, T. R. 1972. A practical handbook of seawater analysis. - Bull. Fish. Res. Board Can. 167: 1-311.

Stumpf, R. P., Frayer, M. L., Durako, M. J. and Brock, J. C. 1999. Variation in water clarity and bottom albedo in Florida Bay. - Estuaries 22: 431-444.

Tilman, D. 1988. Plant strategies and the dynamics and structure of plant communities. - Princeton Univ. Press, $360 \mathrm{p}$

Tilman, D. 1994. Competition and biodiversity in spatially structured habitats. - Ecology 75: 2-16.

Vitousek, P. M. and Reiners, W. A. 1975. Ecosystem succession and nutrient retention: a hypothesis. - BioScience 25 : $376-381$.

Wiginton, J. R. and McMillan, C. 1979. Chlorophyll composition under controlled light conditions as related to the distribution of seagrasses in Texas and the U.S Virgin Islands. - Aquat. Bot. 6: 171-184.

Williams, S. L. 1990. Experimental studies in Caribbean seagrass bed development. - Ecol. Monogr. 60: 449-469.

Zieman, J. C. 1982. The ecology of the seagrasses of south Florida: a community profile. - U.S. Fish and Wildlife Services. Office of Biological Services: Washington, D.C. FWD/OBI-82/25, 158 pp. 